economy. The country is still trying to dig itself out of an economic crisis. External accreditation may have the same result-self-imposed external discipline unrelated to local conditions with potentially dangerous effects.

U.S. accreditation will also place pressure on other local institutions that are not part of the accreditation process. If U.S-accredited schools are considered in the local market to be the "best" because of their American imprimatur and confer upon their standards a better chance of gaining access to American graduate schools, this outcome will have an impact on the rest of the academic system. It is also likely that U.S. accreditation will take place mainly in the private sector, thereby strengthening the private institutions at the expense of public universities.

American accreditation overseas will be expensive, and the cost will be borne by the foreign universities. The U.S. accrediting system is financed by the institutions being accredited-the members of the accreditation consortium. Foreign institutions will need to pay these fees, which are costly-and overseas costs are likely to be significantly higher due to travel and other expenses. It is also unclear if foreign institutions will be welcomed into full membership in the various accrediting groups.

\section{What Should Be Done?}

International accreditation is an important issue in part because it is related to the larger subject of quality assurance. The issues are complex and intertwined. There is an obvious need to measure academic quality and performance in increasingly diversified academic systems, to rank academic institutions and programs, and to define academic achievement. As universities increasingly seek to recruit students and place graduates internationally, international recognition becomes more important. U.S. accreditation seems like a quick fix. American accreditors may feel that they are performing a service to universities in other countries who ask for accreditation. But it is neither possible nor desirable simply to wave a "magic wand" of U.S. accreditation over foreign institutions to grant them instant respectability.

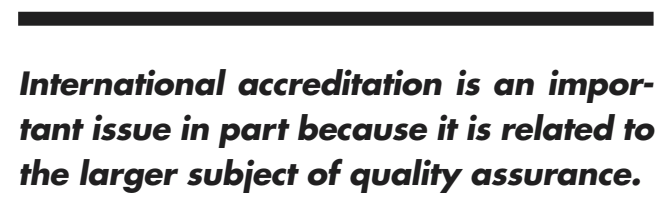

The complex issues of quality assurance and accreditation must be thought through. International discussions can help to clarify issues. But solutions must take into account national and regional circumstances.
An international solution is unlikely to succeed, and simply adopting the norms and systems of the world's most powerful academic system is definitely a flawed idea. It is possible that regional accreditation may be possible-for example, in regions like Central America or perhaps Arab countries. Once the "Bologna process" is implemented within the European Union, some kind of regional quality assurance or accreditation arrangement may be useful. The United States has a long and largely successful history of accrediting academic institutions and programs, although it should be kept in mind that U.S. accreditation provides a "floor" of minimum quality rather than a measurement of top achievement. The American experience can be studied as one model of accreditation, but it should not be exported-in the long run this is neither a service to those institutions currently clamoring for it nor a positive contribution of American accreditors.

\section{A Case Study in Foreign Degree (Dis)approval}

\section{Alan L. Contreras}

Alan L. Contreras is administrator of the Oregon Office of Degree Authorization (ODA), a unit of the Oregon Student Assistance Commission. $\mathrm{He}$ also serves as director of OSAC's policy and research division. The opinions expressed here do not necessarily represent those of the OSAC. Address: ODA-OSAC, 1500 Valley River Dr., Eugene OR 97401. Email: alan.L.contreras@state.or.us.

$\mathrm{D}$ uring the past few months, several regulatory and advisory organizations in the United States have become aware of an interesting case involving the international validation of degrees. Certain Liberian officials have apparently authorized a privately owned entity called the "National Board of Education" (NBOE) to "accredit" distance-education colleges anywhere in the world. The NBOE also owns one such entity, a diploma mill called St. Regis University. The only known "address" of the "Liberian" National Board of Education is National Board of Education, Inc., Washington DC 20003, Phone/Fax: 12024781779.

Because Oregon law requires that foreign degrees be from schools having the foreign equivalent of U.S. accreditation, the ODA had reason to look into the precise nature of these entities. What we found was disturbing in its potential consequences for so-called "seamless" international portability of postsecondary credentials.

The NBOE offers accreditation for a fee, with no apparent evaluation process other than a nominal 
application. No legitimate accreditor would do this. Indeed, the fee is simply sent in on-line, there is not even a real mailing address for NBOE, as far as we can tell. This arrangement is typical of operations falsely claiming to offer legitimate college accreditation.

Among its many services, the NBOE offers what it claims are verification apostilles of the kind used by jurisdictions worldwide to validate a degree. The NBOE claims that these apostilles can be issued with a Washington, D.C. seal, which in effect declares the degree to be a U.S. degree, not a Liberian degree, for a fee of $\$ 1,200$ per item. By comparison, a legitimate apostille issued by the Oregon secretary of state costs $\$ 10$. Of course, a legitimate Liberian apostille could not bear a U.S. seal.

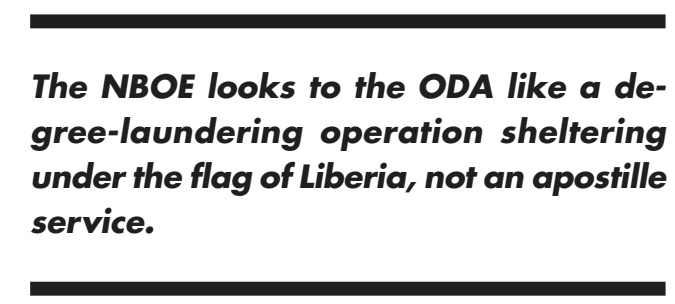

The NBOE looks to the ODA like a degreelaundering operation sheltering under the flag of Liberia, not an apostille service. We have no idea upon what basis a dubious Liberian postsecondary accreditor is using a Washington, D.C. seal to approve individual degrees. Inquiries about NBOE's apostille services in March 2003 were redirected to an entity called Interfaith Education Ministries (http://www.interfaithedu.org/Members.htm), which purports to be an accreditor but in fact only lists diploma mills and substandard providers on its list of accredited schools.

In its spare time, the NBOE offers a transcript service for existing schools. Legitimate accreditors do not issue transcripts - colleges do. For which schools is the NBOE issuing transcripts, besides St. Regis, which it owns outright? Who knows? In order for Oregon to determine whether the NBOE would be considered a legitimate accreditor, we would need to know the following information in order to begin an evaluation: who operates the National Board of Education, including owners, board members and shareholders, and their addresses; where the NBOE's office and corporate assets are actually located; the names and addresses of any person employed by the NBOE in the United States; the process through which it obtained approval from the government of Liberia to accredit colleges; and a complete list of the colleges that it accredits and what they did to obtain accreditation. None of this information is available from the NBOE website nor was it provided by the Liberian embassy in Washington when they wrote to us.
The relationship between the NBOE, the Liberian government, and certain diploma mills is so convoluted that even Liberian officials get confused. In a letter sent to the ODA by its embassy in the United States, Liberia's first secretary and consul stated that Liberia "will not verify the accreditation" of Adam Smith University, even though it was recently listed as an NBOE-accredited school.

On its website in March 2003, Adam Smith University, a diploma mill with a long and unattractive history spent among several U.S. states and territories, states the following: "Adam Smith University is accredited by the Ministry of Education of the Republic of Liberia." This site also states: "Degrees are conferred from a charter issued in the United States of America by the Commonwealth of the Northern Mariana Islands or from Liberia or the British Virgin Islands if a student prefers one of these jurisdictions." It offers the following address, among others: "Adam Smith University Liberia, Inc., Ground Floor Girls Hostel, Methodist Compound, 13th Street, Sinkor, P.O. Box 6046, Monrovia, Liberia/ West Africa, Cell Phone: 0113774706516143, Fax: 231227869, email: Vblama@yahoo.com."

How should the State of Oregon evaluate this garish, unwholesome collage of facts about a "governmentapproved" foreign accreditor and its progeny? Even if we could locate the NBOE, little about it seems Liberian, national, boardlike, or educational to the ODA, though we'll provisionally concede the "Inc." If the Liberian government did not approve all of these entities we would have expected it to have taken legal action to compel their removal.

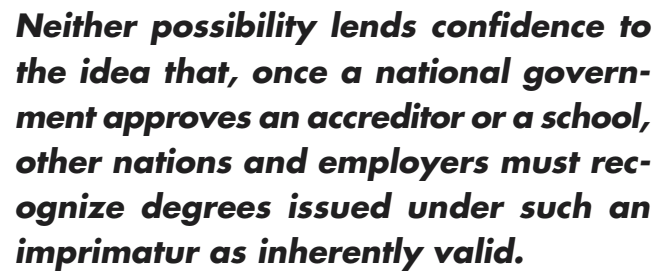

In the continued presence of filiative statements in multiple international venues, it is not unreasonable for the State of Oregon to assume that some formal oversight relationship exists between the entities and the government of Liberia. This in turn suggests that the Liberian government has no meaningful postsecondary oversight in place or that a network of its officials is freelancing. Neither possibility lends confidence to the idea that, once a national government approves an accreditor or a school, other nations and employers must recognize degrees issued under such an imprimatur as inherently valid. 
The State of Oregon has concluded that the NBOE is not a legitimate accrediting body-based on the many obscure statements made on its website, the absence of a list of its accredited schools, its apostille service in the shape of a spigot, its clear connection to known diploma mills, and the absence of any but the most tenuous connection to Liberia.

It is possible that the government of Liberia has been deceived regarding the true nature of the NBOE and its subsidiary entities. We have asked the U.S. Embassy in Monrovia to investigate this situation. It is somewhat impractical for a single U.S. state to investigate sharp practices on other continents, but there is no other government entity in the United States, including the U.S. Department of Education, that appears willing to act against the Jolly Rogers sailing under such obvious flags of educational convenience.

\section{Mapping the Education Industry: Public Companies and Higher Education \\ Richard Garrett}

Richard Garrett is deputy director, Observatory on Borderless Higher Education, John Foster House, 36 Gordon Square, London WC1H OPF, UK. Email: r.garrett@obhe.ac.uk.

A $\mathrm{n}$ important aspect of contemporary higher education is the growing role of commercial entities in certain aspects of teaching and learning. The Observatory on Borderless Higher Education, an international strategic information service based in the United Kingdom, recently published two reports. The first looked at the share price and financial results of 50 companies from 10 countries operating in the broad area of postsecondary education. This report introduced the Global Education Index-an index of the share price of these firms, including analysis by type and country. The second report positioned these companies in relation to nonprofit higher education and explored emerging relationships between the two sectors. This article provides a summary of the second report. The full report is available to institutions that subscribe to the Observatory on Borderless Higher Education (see www.obhe.ac.uk) and contains details of the companies and methodology.

The extent to which education companies pose a threat to nonprofit higher education is a matter of considerable hype and speculation. This review of company activities and relationships sought to marshal the available evidence. Companies generally fell into one of three types: direct competitors, with little or no other relationship with the nonprofit sector; indirect competitors, serving markets of generally minor or potential interest to the nonprofit sector; and service providers and clients, offering a range of services to nonprofit higher education or benefiting from particular services from nonprofit higher education.

\section{The extent to which education compa- nies pose a threat to nonprofit higher education is a matter of considerable hype and speculation.}

Type 1 is exemplified by the independent for-profit university or college networks in the United States. These institutions offer their own degree provision, have standard regional or specialist accreditation, and specialize in market segments that are important to many nonprofit higher education institutions. Examples include the Apollo Group, Sylvan Learning Systems, Career Education, and Corinthian Colleges. Type 2 concerns the various e-learning and human capital development firms focused on the corporate and government sectors. These companies offer specialist software, courses, and related services, with a strong emphasis on business and technology development. This territory overlaps with the remit of many business schools in higher education, but would generally not be regarded as the latter's core business (particularly the emphasis on software development and delivery). Example companies include DigitalThink, SkillSoft, Saba, and Centra.

Type 3 is more complex. Companies of this type provide a range of services to nonprofit higher education including provision of learning management software, marketing on-line course material, creation of on-line portals to promote the awards of particular universities overseas, development of outsourced course design and delivery for specialized areas of the curriculum, and funding for new ventures. Nonprofit higher education institutions also provide services to these companies, particularly franchised degree-awarding powers and academic credit for company courses. Example companies include Thomson Learning, INTI Universal Holdings, NIIT, and Informatics.

Some companies do not fit neatly into a single type. Some offer services to the nonprofit sector but also operate forms of indirect or even direct competition. It is helpful to think of relationships between companies 